\title{
Purification and properties of carboxynorspermidine decarboxylase, a novel enzyme involved in norspermidine biosynthesis, from Vibrio alginolyticus
}

\author{
Hiroshi NAKao, Sumio Shinoda and Shigeo Yamamoto* \\ Faculty of Pharmaceutical Sciences, Okayama University, Tsushima, Okayama 700, Japan
}

(Received 16 March 1990; revised 15 May 1990; accepted 21 May 1990)

\begin{abstract}
A novel enzyme which catalyses the decarboxylation of carboxynorspermidine $\left[\mathrm{H}_{2} \mathrm{~N}\left(\mathrm{CH}_{2}\right)_{3} \mathrm{NHCH}_{2} \mathrm{CH}_{2}\right.$ $\left.\mathrm{CH}\left(\mathrm{NH}_{2}\right) \mathrm{COOH}\right]$ to yield norspermidine $\left[\mathrm{H}_{2} \mathrm{~N}\left(\mathrm{CH}_{2}\right)_{3} \mathrm{NH}\left(\mathrm{CH}_{2}\right)_{3} \mathrm{NH}_{2}\right]$, one of the unusual polyamines, was purified to apparent homogeneity (3100-fold) from cells of Vibrio alginolyticus. The enzyme has an apparent $M_{\mathrm{r}}$ of 86000, with a pI of $4 \cdot 25$, and is a dimer composed of identical subunits with an apparent $M_{\mathrm{r}}$ of 43500 . The $K_{\mathrm{m}}$ for carboxynorspermidine was $175 \mu \mathrm{M}$ and for pyridoxal $5^{\prime}$-phosphate, $4.8 \mu \mathrm{M}$. The purified preparation had a specific activity of $24 \cdot 1 \mu \mathrm{mol}$ norspermidine produced $\mathrm{min}^{-1}\left(\mathrm{mg}^{2}\right.$ protein) ${ }^{-1}$. Carboxyspermidine, a structural homologue, was able fully to replace carboxynorspermidine as a substrate, to produce spermidine, but neither 2,3diaminopropionic acid, 2,4-diaminobutyric acid, ornithine nor lysine showed detectable substrate activity. The optimum pH was 8.25. Dithiothreitol greatly stimulated the enzyme activity, maximum stimulation being observed at more than $5 \mathrm{mM}$-dithiothreitol.
\end{abstract}

\section{Introduction}

The aminopropyl moieties in spermidine (SPD) and spermine molecules arise from two biological pathways. One operates in a wide variety of prokaryotes and eukaryotes, and utilizes $S$-adenosyl-L-methionine, via its decarboxylated product, as an aminopropyl group donor (Williams-Ashman \& Pegg, 1981). The enzymes responsible, aminopropyltransferases, have been characterized extensively in many organisms (Tabor \& Tabor, 1985; Pegg, 1986). An analogous reaction has been suggested in the synthesis of newly discovered polyamines such as 2-hydroxyspermidine, norspermidine (NSPD) and norspermine (Rosano et al., 1978; De Rosa et al., 1978; Paulin et al., 1983; Aleksijevic et al., 1979; Villanueva et al., 1980). The other pathway, as yet detected only in certain bacteria (Tait, 1985) and seedlings of a plant (Srivenugopal \& Adiga, 1980), utilizes L-aspartic acid via its conversion to $\mathrm{L}$-aspartic $\beta$-semialdehyde (ASA) as an aminopropyl-group donor. In this pathway, the Schiff base complex formed non-enzymically between ASA and

Abbreviations: NSPD, norspermidine; C-NSPD, L-carboxynorspermidine; SPD, spermidine; C-SPD, L-carboxyspermidine; DABA, L-2,4-diaminobutyric acid; ASA, L-aspartic $\beta$-semialdehyde; PLP, pyridoxal 5'-phosphate; DTT, dithiothreitol; DAP, 1,3diaminopropane. putrescine is converted into SPD through two enzyme reactions. However, the enzymes, Schiff base reductase and carboxyspermidine (C-SPD) decarboxylase, that catalyse these reactions have not yet been purified and so are less well characterized.

We have previously shown that NSPD is widely distributed in the genus Vibrio as a major triamine species (Yamamoto et al., 1983). Our attempts to elucidate the biosynthetic pathway for this polyamine in some Vibrio species have indicated that $\mathrm{L}$-aspartic acid (via ASA) also serves as an aminopropyl donor (Yamamoto et al., 1986a). The Schiff base $\left[\mathrm{H}_{2} \mathrm{~N}\left(\mathrm{CH}_{2}\right)_{3} \mathrm{~N}=\mathrm{CHCH}_{2} \mathrm{CH}\left(\mathrm{NH}_{2}\right) \mathrm{COOH}\right]$ formed between ASA and 1,3-diaminopropane (DAP) was converted into NSPD by crude cell extracts in the presence of both NADPH and pyridoxal 5'-phosphate (PLP). At present, such a mode of NSPD biogenesis is not known in any other organisms. Recently, we have purified to homogeneity a novel enzyme, L-2,4-diaminobutyric acid (DABA) decarboxylase (EC 4.1.1.-), which is responsible for the production of DAP as an amine precursor for NSPD in $V$. alginolyticus (Nakao et al., 1989). In this study, a second novel enzyme, which catalyses the decarboxylation of L-carboxynorspermidine (C-NSPD) to yield NSPD, has been purified to homogeneity from $V$. alginolyticus and characterized. 


\section{Methods}

Bacterial strain and growth conditions. Vibrio alginolyticus ATCC 17749 was grown for 6-8 h as described previously (Nakao et al., 1989), and the cell pellets collected were stored at $-30^{\circ} \mathrm{C}$ until enzyme purification.

Preparation of C-NSPD and C-SPD. We first attempted to synthesize the substrate C-NSPD chemically, according to the procedure of Srivenugopal \& Adiga (1980), but could only obtain very low yields. Therefore, we prepared it from DAP and ASA by the action of the $V$. alginolyticus Schiff base reductase. ASA was prepared by ozonolysis of L-allylglycine and purified (Black \& Wright, 1955). The enzyme preparation employed was the $\left(\mathrm{NH}_{4}\right)_{2} \mathrm{SO}_{4}$ fraction $(50-70 \%$ saturation) as described below. The incubation medium consisted of $125 \mathrm{~mm}$-potassium phosphate buffer, pH 7.5, 2.2 mM-NADPH, $5 \mathrm{~mm}$-dithiothreitol (DTT), $7 \mathrm{~mm}$-DAP, $5 \mathrm{~mm}$-ASA and $30 \mathrm{mg}$ of protein in a total volume of $7 \mathrm{ml}$. Fifty test tubes, each containing the above medium, were incubated at $37^{\circ} \mathrm{C}$ for $2 \mathrm{~h}$. The reaction was terminated by the addition of $2.4 \mathrm{ml} 20 \%$ (w/v) $\mathrm{HClO}_{4}$ to each tube, and the precipitate was removed by centrifugation. The combined supernatant was applied to a column $(2.7 \times 11 \mathrm{~cm})$ of Amberlite CG-120, 100-200 mesh, in the $\mathbf{H}^{+}$form. The column was washed with $400 \mathrm{ml}$ distilled water, followed by $400 \mathrm{ml} 1.5 \mathrm{M}-\mathrm{HCl}$, and then eluted with $400 \mathrm{ml} 6 \mathrm{M}-\mathrm{HCl}$. The eluate was evaporated to dryness at $60^{\circ} \mathrm{C}$ in a rotary evaporator under reduced pressure. The residue, dissolved in a small volume of $0.1 \mathrm{M}-\mathrm{HCl}$, was applied to a column $(2.7 \times 11 \mathrm{~cm})$ of Dowex $50 \mathrm{~W} \times 8,200-400$ mesh, in the $\mathrm{H}^{+}$form. After washing with $400 \mathrm{ml}$ distilled water followed by $200 \mathrm{ml}$ each of $1,1.5$ and $2 \mathrm{M}-\mathrm{HCl}$ the column was eluted with a stepwise increase in the concentration of $\mathrm{HCl}(0.1 \mathrm{M}$ per $50 \mathrm{ml})$. Three fractions, eluting with $2.7-2.9 \mathrm{M}-\mathrm{HCl}$, were pooled and evaporated to dryness. The resulting oil was recrystallized with water/2-propanol to give approximately $220 \mathrm{mg}$ of C-NSPD trihydrochloride: m.p. $231-232^{\circ} \mathrm{C} ;[\alpha]_{\mathrm{D}} \pm 12^{\circ}(1 \%$, w/v, in $\mathrm{H}_{2} \mathrm{O}$ ).

The $\left(\mathrm{NH}_{4}\right)_{2} \mathrm{SO}_{4}$ precipitate $(50-70 \%$ saturation) from Paracoccus denitrificans IFO 13301 (NCIB 8944), which possesses a pathway for the production of SPD via C-SPD (Tait, 1985), was employed for the preparation of C-SPD. Cells grown for $5 \mathrm{~h}$ under the same conditions as those for $V$. alginolyticus were used as the enzyme source. Incubation and purification were done as described above except that DAP was substituted for putrescine. C-SPD was eluted in the 2.8 and $2.9 \mathrm{M}-\mathrm{HCl}$ fractions from a column of Dowex $50 \mathrm{~W} \times 8$. Recrystallization of the residue with the same solvents as those for C-NSPD gave $50 \mathrm{mg}$ of C-SPD trihydrochloride: m.p. $221-222^{\circ} \mathrm{C} ;[\alpha]_{\mathrm{D}} \pm 5 \cdot 8^{\circ}(1 \%$, w/v, in $\mathrm{H}_{2} \mathrm{O}$ ).

The identity and purity of these compounds were confirmed by GC, GC-MS (Yamamoto et al., 1986a) and TLC on an Avicel SF cellulose plate (Funakoshi Pharmaceutical Co., Japan) in a solvent system of ethanol/ammonium hydroxide/water $(18: 5: 1$, by vol.). No contaminating materials which provided GC peaks and reacted with ninhydrin were present in any preparation. The $R_{\mathrm{F}}$ values for C-NSPD and C-SPD were 0.40 and 0.44 respectively.

Enzyme assay. The production of NSPD was assayed in the standard mixture $(1.0 \mathrm{ml})$, containing $100 \mu \mathrm{mol}$ Tris $/ \mathrm{HCl}$ buffer, $\mathrm{pH} 8.25$, $1.4 \mu \mathrm{mol}$ C-NSPD, $0.1 \mu \mathrm{mol}$ PLP, $5 \mu \mathrm{mol}$ DTT and enzyme protein $(0.1-100 \mu \mathrm{g})$, incubated at $37^{\circ} \mathrm{C}$ for $30 \mathrm{~min}$. After termination of the reaction with $0.4 \mathrm{ml}$ of $20 \%(\mathrm{w} / \mathrm{v}) \mathrm{HClO}_{4}$, an internal standard (1,10-diaminooctane) was added to the mixture, which was then centrifuged at $1500 \mathrm{~g}$ for $10 \mathrm{~min}$. The supernatant was treated for derivatization, followed by GC analysis with nitrogen-selective detection, as previously described (Yamamoto et al., 1986a). The reproducibility of the method used was assessed by calculating the recoveries of known amounts of NSPD ( 50 and $100 \mathrm{nmol})$ added to the assay mixtures denatured by the prior addition of $\mathrm{HClO}_{4}$. The recovery for NSPD was $97 \pm 6 \%(n=10)$. Also, under standard assay conditions, enzyme activity was a linear function of both incubation time (5-120 min) and the amount of enzyme protein present. One unit of activity $(U)$ was defined as the amount of enzyme that catalysed the formation of $1 \mu \mathrm{mol} \mathrm{NSPD} \mathrm{min}^{-1}$ under standard assay conditions.

Enzyme purification. Unless otherwise noted, all procedures were done at $2-4^{\circ} \mathrm{C}$ and all dialyses were done against 100 vols of the specified buffers for $12 \mathrm{~h}$. A crude estimate of the protein content of column fractions was made by measuring absorbance at $280 \mathrm{~nm}$. For accurate measurement of the protein content of pooled column fractions and final enzyme preparation the Lowry method or that of Bradford (1976) was used depending upon the amount of material available.

(i) The frozen cells $(200 \mathrm{~g})$ were thawed and suspended in $800 \mathrm{ml}$ $20 \mathrm{~mm}$-Tris/ $\mathrm{HCl}, \mathrm{pH} 7.5$, containing $1 \mathrm{~mm}$-DTT and $0.1 \mathrm{~mm}$-EDTA (buffer A). Samples consisting of $200 \mathrm{ml}$ of cell suspension were placed in $500 \mathrm{ml}$ beakers kept in a salt-ice bath and sonicated with an ultrasonic homogenizer. Cell debris was removed by centrifugation at $40000 \mathrm{~g}$ for $30 \mathrm{~min}$, and a small portion of the combined supernatant dialysed against buffer $\mathrm{A}$ to determine the activity.

(ii) Solid $\left(\mathrm{NH}_{4}\right)_{2} \mathrm{SO}_{4}$ was added slowly, with stirring, to the combined supernatant, to give a final concentration of $50 \%$ saturation. The solution was centrifuged at $35000 \mathrm{~g}$ for $20 \mathrm{~min}$ and the pellet discarded. Additional $\left(\mathrm{NH}_{4}\right)_{2} \mathrm{SO}_{4}$ was added to the supernatant to obtain a final concentration of $70 \%$ saturation, and the new precipitate was centrifuged as above. The pellet was dissolved in buffer $A$ and dialysed against two changes of the same buffer.

(iii) The dialysed $\left(\mathrm{NH}_{4}\right)_{2} \mathrm{SO}_{4}$ fraction $(60 \mathrm{ml})$ was divided into three $20 \mathrm{ml}$ portions, each of which was applied to a DEAE-Sepharose CL-6B column $(2.2 \times 25 \mathrm{~cm})$ equilibrated with buffer $A$. The column was washed with $300 \mathrm{ml}$ of buffer $\mathrm{A}$ containing $0.2 \mathrm{M}-\mathrm{NaCl}$ and then eluted with a $500 \mathrm{ml}$ linear gradient of $0.2-0.4 \mathrm{M}-\mathrm{NaCl}$ in the same buffer at a flow rate of $15 \mathrm{ml} \mathrm{h}^{-1}$. Active fractions eluting between 0.32 and $0.33 \mathrm{M}-\mathrm{NaCl}$ were pooled $(25 \mathrm{ml} \times 3)$.

(iv) The pooled fraction of step (iii) was treated with solid $\left(\mathrm{NH}_{4}\right)_{2} \mathrm{SO}_{4}$ to bring it to $80 \%$ saturation, and the precipitate was collected and dissolved in a small amount of buffer $\mathrm{A}$, containing $0.4 \mathrm{M}-\mathrm{NaCl}, 40 \mu \mathrm{M}$-PLP and $0.02 \% \mathrm{NaN}_{3}$. The solution was applied to a Sephacryl S-200 HR column $(2.1 \times 88 \mathrm{~cm})$ equilibrated with the same buffer and the column was eluted with the same buffer at a flow rate of $10 \mathrm{ml} \mathrm{h}^{-1}$. Active fractions (tube nos 31-33) were pooled (15 ml).

(v) After dialysis against $20 \mathrm{~mm}$-sodium phosphate buffer, $\mathrm{pH} 5.8$, containing $1 \mathrm{mM}$-DTT and $0.1 \mathrm{mM}$-EDTA, the step (iv) fraction was applied to a DEAE-Sepharose CL-6B column $(1.3 \times 20 \mathrm{~cm})$ equilibrated with the same buffer. The column was washed with $80 \mathrm{ml}$ of the above buffer, additionally containing $0.25 \mathrm{M}-\mathrm{NaCl}$, and then eluted with a $200 \mathrm{ml}$ linear gradient of $0.25-0.75 \mathrm{M}-\mathrm{NaCl}$ in the same buffer at a flow rate of $10 \mathrm{ml} \mathrm{h}^{-1}$. Active fractions eluting between 0.42 and $0.45 \mathrm{M}-\mathrm{NaCl}$ were pooled $(15 \mathrm{ml})$.

(vi) The active fraction was dialysed against $10 \mathrm{~mm}$-potassium phosphate buffer, pH 7.5, containing $1 \mathrm{mM}$-DTT and $0.1 \mathrm{mM-EDTA}$, and the dialysed solution was applied to a hydroxyapatite column $(1.65 \times 10.5 \mathrm{~cm})$ equilibrated with the same buffer. After washing with $120 \mathrm{ml}$ of the same buffer, the column was eluted with a $120 \mathrm{ml}$ linear

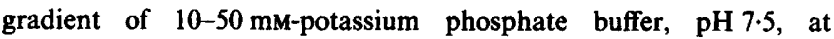
a flow rate of $10 \mathrm{ml} \mathrm{h}^{-1}$. Active fractions eluting between 39 and $42 \mathrm{~mm}$-potassium phosphate were pooled $(12 \mathrm{ml})$.

(vii) Chromatofocusing was done according to the supplier's instructions (Technical Handbook: Chromatofocusing with Polybuffer and PBE, Pharmacia, Uppsala). A PBE column $(0.95 \times 14.5 \mathrm{~cm})$ was equilibrated with $25 \mathrm{mM}$-piperazine/ $\mathrm{HCl}$ buffer, $\mathrm{pH} 5.5$, containing 1 mM-DTT. The original Polybuffer 74 was diluted 10 -fold by vol. with $1 \mathrm{mM}$-DTT solution, adjusted to $\mathrm{pH} 4 \cdot 0$ with $0 \cdot 1 \mathrm{M}-\mathrm{HCl}$ and degassed. 
The step (vi) enzyme solution which had been dialysed against the same buffer was applied to the column, followed by elution with $180 \mathrm{ml}$ of Polybuffer 74, pH 4.0. However, C-NSPD decarboxylase activity was not observed in any fraction, although the $\mathrm{pH}$ of fractions monitored at the same time dropped linearly to $\mathrm{pH} 4$. The column was then eluted with $20 \mathrm{~mm}-\mathrm{Tris} / \mathrm{HCl}$ buffer, $\mathrm{pH} 7.5$, containing $1 \mathrm{M}-\mathrm{NaCl}$ and $1 \mathrm{mM}$-DTT; $3 \mathrm{ml}$ fractions were collected. Activity was recovered in fraction 6 , which was dialysed against buffer A containing $0.02 \%$ $\mathrm{NaN}_{3}$ and stored at $4{ }^{\circ} \mathrm{C}$ after concentration to about $0.25 \mathrm{ml}$ by use of a Centricon 30 (Amicon)

Electrophoretic analyses. PAGE under non-denaturing conditions was done on a $7.5 \%(\mathrm{w} / \mathrm{v})$ polyacrylamide slab gel as described by Williams \& Reisfeld (1964) except that DTT was added to buffers for preparation of gels to give a final concentration of $1 \mathrm{mM}$. SDS-PAGE was done by using a $10 \%(\mathrm{w} / \mathrm{v})$ polyacrylamide slab gel according to Laemmli (1970). Before loading, the enzyme sample was heated for $3 \mathrm{~min}$ with $2 \%(\mathrm{w} / \mathrm{v})$ SDS and $5 \%(\mathrm{w} / \mathrm{v}) 2$-mercaptoethanol in a boilingwater bath. Isoelectric focusing was done on a $5 \%(\mathrm{w} / \mathrm{v})$ polyacrylamide gel plate containing $2 \%(\mathrm{w} / \mathrm{v})$ Ampholine $\mathrm{pH} 3.5-9.5$ using a horizontal isoelectric focusing apparatus (Bio-Rad, model 1415). The samples were run at an initial setting of $4 \mathrm{~W}$ for $2 \mathrm{~h}$, at $1500 \mathrm{~V}$ for $3 \mathrm{~h}$ and then at $1700 \mathrm{~V}$ for $30 \mathrm{~min}$. Protein bands were visualized by staining with Coomassie Brilliant Blue R-250. For monitoring the distribution of enzyme activity after native PAGE, the gels were sliced horizontally into $5 \mathrm{~mm}$ sections, each of which was macerated in buffer A overnight at $4{ }^{\circ} \mathrm{C}$ to elute the enzyme.

Determination of $M_{r}$ by gel filtration and SDS-PAGE. The $M_{\mathrm{r}}$ of the native enzyme was determined, as described by Andrews (1965), by using a Sephacryl S-200 HR column $(2 \cdot 1 \times 88 \mathrm{~cm})$ calibrated with protein standards. The $M_{\mathrm{r}}$ of the subunit was determined from the relative mobility on SDS-PAGE compared to the standards.

Chemicals. Diamines and polyamines were purchased from Aldrich; DEAE-Sepharose CL-6B, Sephacryl S-200 HR, PBE 94, Polybuffer 74 and Ampholine were from Pharmacia LKB; DTT, PLP, L-allylglycine, standard protein kit for SDS-PAGE (SDS-6H) and standard proteins for gel filtration were from Sigma; and NADPH and hydroxyapatite were from Oriental Yeast (Japan) and Wako (Japan), respectively.

\section{Results}

Preliminary experiments with a crude cell extract containing the whole enzyme system for NSPD biosynthesis showed that no NSPD was formed unless incubation was first done in the presence of NADPH.
This at least indicates that decarboxylation of the Schiff base complex is not a first-step reaction. The reaction sequence has thus been shown to be:

$$
\mathrm{DAP}+\mathrm{ASA} \rightarrow \text { Schiff base } \rightarrow \mathrm{C}-\mathrm{NSPD} \rightarrow \mathrm{NSPD}+\mathrm{CO}_{2}
$$

\section{Purification of C-NSPD decarboxylase}

The steps followed in the purification of C-NSPD decarboxylase from $V$. alginolyticus ATCC 17749 are shown in Table 1. C-NSPD decarboxylase appeared to be a completely cytoplasmic enzyme, found in the $\mathrm{S} 40$ cell-free extract. The first DEAE-Sepharose CL-6B chromatography led to a $9 \%$ increase in the total enzyme activity of the crude extract, with a large increase in purification. The increase in the total activity suggests the possible presence of an enzyme inhibitor(s) in the crude extract that was removed. Hydroxyapatite chromatography also brought about a large increase in purification with a good recovery, but some minor contaminating proteins were still detected by PAGE. Chromatofocusing was very convenient for removing these proteins, since the enzyme was recovered by eluting the PBE column with $1 \mathrm{M}-\mathrm{NaCl}$ after extensive washing with Polybuffer 74 . This agreed well with the fact that the enzyme had a relatively low pI (see below).

A total purification of 3130 -fold and a specific activity of $24.1 \mathrm{U}$ (mg protein $)^{-1}$ was obtained after these purification steps.

\section{Properties of the purified enzyme}

Stability. The enzyme was stable at $4{ }^{\circ} \mathrm{C}$ and $\mathrm{pH} 7.5$ in the presence of DTT, EDTA and $\mathrm{NaN}_{3}$ for at least one month. The enzyme was greatly stabilized by the addition of both DTT and EDTA during purification. Surprisingly, the presence of PLP was not essential for maintenance of enzyme activity during the current purification process, although PLP was essential for

Table 1. Purification of carboxynorspermidine decarboxylase from $V$. alginolyticus

A typical purification from $200 \mathrm{~g}$ wet wt of cells is shown.

\begin{tabular}{|c|c|c|c|c|c|}
\hline Step & $\begin{array}{l}\text { Total } \\
\text { protein } \\
(\mathrm{mg})\end{array}$ & $\begin{array}{l}\text { Total } \\
\text { activity } \\
\text { (U) }\end{array}$ & $\begin{array}{c}\text { Specific } \\
\text { activity } \\
{\left[\mathrm{U}(\mathrm{mg} \text { protein })^{-1}\right]}\end{array}$ & $\begin{array}{l}\text { Purification } \\
\quad \text { (-fold) }\end{array}$ & $\begin{array}{c}\text { Recovery } \\
(\%)\end{array}$ \\
\hline Crude extract & 5100 & $39 \cdot 2$ & 0.0077 & 1 & 100 \\
\hline $50-70 \%$ Ammonium sulphate & 2972 & $38 \cdot 3$ & 0.013 & 1.7 & 98 \\
\hline 1st DEAE-Sepharose CL-6B & 234 & $42 \cdot 7$ & $0 \cdot 18$ & $23 \cdot 4$ & 109 \\
\hline Sephacryl S-200 HR & $35 \cdot 5$ & $29 \cdot 2$ & 0.82 & $106 \cdot 5$ & 74 \\
\hline 2nd DEAE-Sepharose CL-6B & 19.9 & $20 \cdot 6$ & 1.04 & $135 \cdot 1$ & 53 \\
\hline Hydroxyapatite & 1.41 & 18.9 & $13 \cdot 40$ & 1740 & 48 \\
\hline Chromatofocusing & 0.384 & $9 \cdot 25$ & $24 \cdot 10$ & 3130 & 24 \\
\hline
\end{tabular}



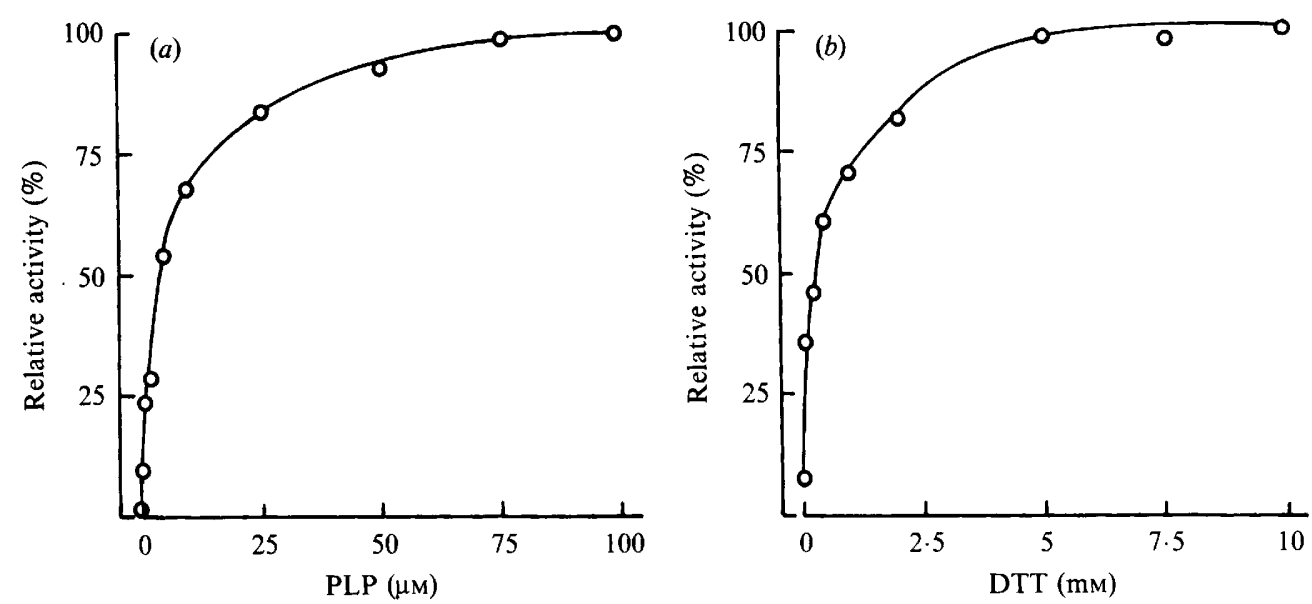

Fig. 1. Cofactor requirement for C-NSPD decarboxylase activity. The purified enzyme $(0 \cdot 1 \mu \mathrm{g})$ was incubated under standard assay conditions except that PLP $(a)$ or DTT $(b)$ was added at the indicated concentrations. In $(b)$, the purified enzyme had been dialysed for $4 \mathrm{~h}$ against two changes of 200 vols $20 \mathrm{mM}$-Tris/ $\mathrm{HCl}$ buffer, $\mathrm{pH} 7.5$, containing $0.1 \mathrm{~mm}$-EDTA, to remove DTT. The relative activity is expressed as a percentage of the maximum activity $(73.3$ and $70.0 \mathrm{nmol}$ NSPD formed in $30 \mathrm{~min}$ for $a$ and $b$, respectively) observed under the experimental conditions.

enzyme activity in the assay (see below). Freezing and thawing the purified preparation resulted in almost complete loss of activity.

Purity and isoelectric point. The purified enzyme migrated as a single protein band in PAGE under non-denaturing conditions (data not shown). Analysis of a duplicate unstained gel for enzyme activity established that the protein band corresponded with the enzyme activity. The protein band with enzyme activity was electrofocused at a pH of $\mathbf{4 \cdot 2 5}$.

$M_{r}$ of enzyme and subunit. The $M_{\mathrm{r}}$ value of the enzyme was determined to be $86000 \pm 1000$ with a Sephacryl S-200 HR column calibrated with standard $M_{\mathrm{r}}$ markers. SDS-PAGE of the purified enzyme showed a single protein band corresponding to an $M_{\mathrm{r}}$ of $43500 \pm 500$, which was unaltered when the protein was not reduced with 2-mercaptoethanol before electrophoresis (data not shown). C-NSPD decarboxylase therefore appears to be a dimer of subunits of identical size, which are not linked by disulphide bonds.

Cofactors required for optimum enzyme activity. When PLP was omitted from the standard assay mixture, the purified enzyme showed only a slight activity, less than $2 \%$ of maximum. Near-maximum stimulation was obtained at $100 \mu \mathrm{M}$-PLP (Fig. 1a). Hyperbolic saturation kinetics were observed for PLP and the $K_{\mathrm{m}}$ value was calculated to be $4.8 \mu \mathrm{M}$. Without addition of DTT to the assay mixture, less than $9 \%$ of the maximum activity was retained in the purified enzyme that had been dialysed for $4 \mathrm{~h}$ against two changes of 200 vols $20 \mathrm{mM}-\mathrm{Tris} / \mathrm{HCl}$ buffer, $\mathrm{pH} 7 \cdot 5$, containing $0 \cdot 1 \mathrm{~mm}$-EDTA. The addition of DTT to the assay mixture, however, brought about a remarkable stimulation of enzyme activity, maximum stimulation being observed at 5-10 mM-DTT (Fig. 1b).

Optimum temperature and $p H$. The optimum temperature for enzyme activity in the standard assay was $37^{\circ} \mathrm{C} ; 75 \%$ and $51 \%$ of the maximum activity remained at $30{ }^{\circ} \mathrm{C}$ and $45^{\circ} \mathrm{C}$, respectively, but the activity decreased rapidly at temperatures above $55^{\circ} \mathrm{C}$ or below $20^{\circ} \mathrm{C}$. The effect of $\mathrm{pH}$ on enzyme activity was determined using $100 \mathrm{~mm}-$ potassium phosphate buffer in the range $6 \cdot 25-7 \cdot 25$, and $100 \mathrm{mM}$-Tris/ $\mathrm{HCl}$ buffer in the range 7.5-9.0. Maximum activity was found at $\mathrm{pH} 8.25 ; 57 \%$ and $72 \%$ of the maximum activity were observed at $\mathrm{pH} 7.5$ and 9.0 , respectively.

Kinetic characteristics and substrate specificity. A Lineweaver-Burk treatment of results obtained when the C-NSPD concentration was varied gave a $K_{\mathrm{m}}$ of $175 \mu \mathrm{M}$ with a $V$ of $26.6 \mu \mathrm{mol}$ NSPD $\mathrm{min}^{-1}(\mathrm{mg} \text { protein })^{-1}$. C-SPD, the alternative substrate, was decarboxylated at almost the same rate as that for C-NSPD, to yield SPD. However, neither L-2,3-diaminopropionic acid, DABA, L-ornithine nor L-lysine served as substrates for C-NSPD decarboxylase. Moreover, none of these diamino acids, at the same concentration as that of C-NSPD (1.4 mM), inhibited the formation of NSPD from C-NSPD.

Influence of cations. The effect of different cations (all $1 \mathrm{~mm}$ ) on the activity of C-NSPD decarboxylase was examined with the purified enzyme. $\mathrm{Fe}^{3+}, \mathrm{Fe}^{2+}$ and $\mathrm{Mn}^{2+}$ severely inhibited the enzyme activity $(88 \%, 82 \%$ and $50 \%$, respectively), whereas $\mathrm{Zn}^{2+}$ had a slightly inhibitory effect $(23 \%)$, and $\mathrm{Mg}^{2+}, \mathrm{Ca}^{2+}, \mathrm{Cu}^{2+}$ and $\mathrm{Cu}^{+}$ had no effect. A substantial loss of activity (about $20 \%$ ) was observed when the enzyme was dialysed for $12 \mathrm{~h}$ or 
stored at $4{ }^{\circ} \mathrm{C}$ for $2 \mathrm{~d}$ without addition of EDTA. $\mathrm{Na}^{+}$ and $\mathrm{K}^{+}$(up to $1 \mathrm{M}$ ) did not affect enzyme activity.

\section{Discussion}

The results presented herein, together with those reported earlier (Yamamoto et al., 1986a), establish the occurrence of a newly recognized decarboxylase participating in NSPD biosynthesis of $V$. alginolyticus. We have designated this enzyme as C-NSPD decarboxylase on the basis of its apparent specificity, and probable role in catalysing the final step in NSPD biosynthesis in vivo. Certainly, the close correspondence between the time of appearance of this enzyme activity and the accumulation of NSPD (Yamamoto et al., 1986b) strongly suggests a functional interrelationship. Nevertheless, it is conceivable that C-NSPD only exists transiently in this bacterium, since our attempts to demonstrate its natural occurrence have not so far been successful. This suggests that the in vivo formation of C-NSPD may be subject to strict regulation by inhibition by the end product, NSPD.

The purification procedures described for C-NSPD decarboxylase from $V$. alginolyticus provided a pure, apparently homogeneous protein in $24 \%$ yield. One important factor contributing to the success of the purification was the efficient preparation of the substrate, C-NSPD, by use of Schiff base reductase from this bacterium. C-NSPD decarboxylase has an $M_{\mathrm{r}}$ of 86000 and is composed of two apparently identical subunits with an $M_{\mathrm{r}}$ of 43500 . As with most decarboxylases, it required PLP for enzyme activity. The $K_{\mathrm{m}}$ value for PLP was calculated at a saturating level of C-NSPD to be $4.8 \mu \mathrm{M}$. However, it is difficult to extrapolate this value to in vivo conditions, because C-NSPD was undetectable in cells. The requirement of the enzyme for DTT, to achieve maximum activity, agreed with the observation for C-SPD decarboxylase of Lathyrus sativus (Srivenugopal \& Adiga, 1980). EDTA was very effective in stabilizing the enzyme, suggesting that it may protect the enzyme from contaminating metal cations.

Interestingly, C-SPD acted as a substrate towards C-NSPD decarboxylase, the reaction rate being comparable with that of C-NSPD. However, the rate of SPD formation was much lower $(<10 \%)$ than that of NSPD formation, when the crude cell extract, having the whole enzymic system for NSPD biosynthesis, was incubated in the presence of putrescine, instead of DAP (Yamamoto et al., 1986a). This suggests that the reductase dependent on NADPH may be more specific to the Schiff base formed between DAP and ASA than that between putrescine and ASA. In contrast, the enzyme was inactive towards DABA, which is structur- ally similar to C-NSPD and C-SPD, indicating that the attachment of an aminopropyl or aminobutyl moiety to the terminal amino group of DABA is essential for substrate activity. On the other hand, whether or not NSPD affects the enzyme activity in vitro could not be clarified because the quantification of NSPD formed enzymically was hampered by the presence of large amounts of added NSPD.

Further efforts will be directed towards purification and characterization of the Schiff base reductase of $V$. alginolyticus to understand the whole biosynthetic pathway for NSPD. The regulatory mechanisms of the enzymes involved in NSPD production, and the importance of NSPD in this bacterium may then be further clarified.

We are indebted to Miss $\mathrm{K}$. Takeuchi for help in preparing C-SPD and to Mr A. Iwadoh for performing GC-MS analyses.

\section{References}

AleksiJevic, A., Grove, J. \& Schuber, F. (1979). Studies on polyamine biosynthesis in Euglena gracilis. Biochimica et Biophysica Acta 565, 199-207.

ANDREWS, P. (1965). The gel-filtration behaviour of proteins related to their molecular weights over a wide range. Biochemical Journal 96, 595-606.

BlaCK, S. \& Wright, N. G. (1955). Aspartic $\beta$-semialdehyde dehydrogenase and aspartic $\beta$-semialdehyde. Journal of Biological Chemistry 213, 39-50.

BRADFORD, M. M. (1976). A rapid and sensitive method for the quantitation of microgram quantities of protein utilizing the principle of protein-dye binding. Analytical Biochemistry 72, 248-254.

De Rosa, M., De Rosa, S., Gambacorta, A., Carteni-Farina, M. \& ZAPPIA, V. (1978). The biosynthetic pathway of new polyamines in Caldariella acidophila. Biochemical Journal 176, 1-7.

LAEMMLI, U. K. (1970). Cleavage of structural proteins during the assembly of the head of bacteriophage T4. Nature, London 227 , 680-685.

NaKaO, H., Ishi, M., Shinoda, S. \& Yamamoto, S. (1989). Purification and some properties of a novel L-2,4-diaminobutyric acid decarboxylase from Vibrio alginolyticus. Journal of General Microbiology 135, 345-351.

Paulin, L., Ruohola, H., Nykänen, I. \& Pösö, H. (1983). The incorporation of 1,3-diaminopropane into thermine by an extreme thermophile: a novel route for the biosynthesis of polyamines. FEMS Microbiology Letters 19, 299-302.

PEgG, A. E. (1986). Recent advances in the biochemistry of polyamines in eukaryotes. Biochemical Journal 234, 249-262.

Rosano, C. L., Hurwitz, C. \& BunCe, S. C. (1978). Newly discovered polyamine, 2-hydroxyspermidine, in Pseudomonas acidovorans. Journal of Bacteriology 135, 805-808.

Srivenugopal, K. S. \& Adiga, P. R. (1980). Coexistence of two pathways of spermidine biosynthesis in Lathyrus sativus seedlings. FEBS Letters 112, 260-264.

TABOR, C. W. \& TABOR, H. (1985). Polyamines in microorganisms. Microbiological Reviews 49, 81-99.

TAIT, G. H. (1985). Bacterial polyamines, structures and biosynthesis Biochemical Society Transactions 13, 316-318.

Villanueva, V. R., Adlakha, R. C. \& Calvayrac, R. (1980) Biosynthesis of polyamines in Euglena gracilis. Phytochemistry 19, 787-790. 
Williams, D. E. \& Reisfeld, R. A. (1964). Disc electrophoresis in polyacrylamide gels: extension to new conditions of $\mathrm{pH}$ and buffer. Annals of the New York Academy of Sciences 121, 373-381.

Williams-Ashman, H. G. \& PeGg, A. E. (1981). Aminopropyl group transfers in polyamine biosynthesis. In Polyamines in Biology and Medicine, pp. 43-73. Edited by D. R. Morris \& L. J. Marton. New York: Marcel Dekker.

Yamamoto, S., Shinoda, S., Kawaguchi, M., Wakamatsu, K. \& Makita, M. (1983). Polyamine distribution in Vibrionaceae: norspermidine as a general constituent of Vibrio species. Canadian Journal of Microbiology 29, 724-728.
Yamamoto, S., Hamanaka, K., Suemoto, Y., Ono, B. \& Shinoda, S. (1986a). Evidence for the presence of a novel biosynthetic pathway for norspermidine in Vibrio. Canadian Journal of Microbiology 32, 99-103.

Yamamoto, S., Yoshida, M., Nakao, H., Koyama, M., Hashimoto, Y. \& SHINODA, S. $(1986 b)$. Variations in cellular polyamine compositions and contents of Vibrio species during growth in media with various $\mathrm{NaCl}$ concentrations. Chemical and Pharmaceutical Bulletin 34, 3038-3042. 